\title{
Intrasellar Chordoma Associated with a Primitive Persistent Trigeminal Artery
}

\section{Primitif Persistan Trigeminal Arterle İlişkili Intrasellar Kordoma}

\author{
Marta NAVAS ${ }^{1}$, Pedro MARTÍNEZ ${ }^{1}$, Sophia F. SHAKUR 2 , Antonio BARBOSA ${ }^{3}$, Eduardo BARCENA ${ }^{3}$, \\ Carlos GORDILLO ${ }^{4}$, Javier FRAGA ${ }^{4}$, Concepcion BLANCO ${ }^{5}$, Rafael G. SOLA ${ }^{1}$ \\ ${ }^{1}$ La Princesa University Hospital, Department of Neurosurgery, Madrid, Spain \\ ${ }^{2}$ La Princesa University Hospital, Department of Neuroradiology, Madrid, Spain \\ ${ }^{3}$ La Princesa University Hospital, Department of Pathology, Madrid, Spain \\ ${ }^{4}$ Principe de Asturias University Hospital, Department of Endocrinology, Madrid, Spain \\ ${ }^{5}$ The University of Chicago Medical Center, Department of Neurosurgery, Chicago, USA
}

Corresponding Author: Marta NAVAS / E-mail: m_navas_garcia@hotmail.com

\begin{abstract}
Chordomas located primarily in the sellar region are uncommon, and may be misdiagnosed non-functioning pituitary adenoma. Furthermore, the association of a persistent primitive trigeminal artery (PPTA) with an intrasellar chordoma is extremely rare, and no similar cases have been reported in the literature to date. The coexistence of intrasellar chordoma (ISC) and PPTA makes safe and complete tumor resection challenging, and preoperative endovascular occlusion of this artery may be helpful.

We report a case of a 32-year-old man who developed right hemifacial paresthesias and a cranial nerve six palsy. MRI study demonstrated the presence of a primary ISC associated with a PPTA. Angiographic balloon test occlusion of the PPTA revealed no neurological changes, so this vessel was endovascularly occluded by coiling. The lesion was subtotally removed through a sublabial transsphenoidal approach, without intraoperative bleeding complications. Histological examination of the lesion was consistent with the diagnosis of chordoma.

Detailed preoperative neurovascular evaluation may be useful to detect vascular anomalies associated with intracranial chordomas, such as PPTA. In this report we emphasize the importance of appropriate treatment of vascular anomalies prior intrasellar lesions resection that may facilitate surgery and avoid potential hazardous intraoperative bleeding complications.
\end{abstract}

KEYWORDS: Chordoma, Intracranial mass, Persistent primitive trigeminal artery, Sellar lesion, Skull base

öz

Temel olarak sellar bölgede bulunan kordomalar nadirdir ve yanlışlıkla işlevsel olmayan pitüiter adenom tanısı konabilir. Ayrıca bir persistan primitif trigeminal arter (PPTA) ile intrasellar kordoma ilişkisi çok nadirdir ve şu ana kadar benzer bir olgu literatürde bildirilmemiştir. İntrasellar kordoma (ISC) ve PPTA'nın birlikte bulunması başarılı ve tam bir tümör rezeksiyonunu zor hale getirir ve arterin preoperatif endovasküler oklüzyonu faydalı olabilir.

Sağ hemifasiyal parestezi ve kraniyal altıncı sinir palsisi gelişen 32 yaşında bir erkek olgu bildiriyoruz. MRG çalışması PPTA ile ilişkili bir primer ISC varlığını gösterdi. PPTA'nın anjiyografik balon test oklüzyonu nörolojik değişikliğe neden olmadığından sarmal (koil) ile bu damar endovasküler olarak tıkandı. Lezyon sublabial transsfenoidal yaklaşımla intraoperatif bir kanama komplikasyonu olmadan subtotal olarak çıkartıldı. Lezyonun histolojik incelemesi kordoma tanısıyla uyumluydu.

Intrakraniyal kordomalarla ilişkili PPTA gibi vasküler anomalileri saptamak için ayrıntılı preoperatif nörovasküler değerlendirme faydalı olabilir. Bu raporda, intrasellar lezyonların rezeksiyonundan önce cerrahiyi kolaylaştırabilecek ve tehlikeli intraoperatif kanama komplikasyonlarından kaçınmayı sağlayacak şekilde vasküler anomalilerin uygun tedavisinin önemini vurguluyoruz.

ANAHTAR SÖZCÜKLER: Kordoma, İntrakraniyal kitle, Persistan primitif trigeminal arter, Sella lezyonu, Kafa tabanı

\section{INTRODUCTION}

Chordomas are midline neoplasms that originate from ectopic cells of notochordal remnants $(18,22)$. The trigeminal artery (TA) is an anastomosis between embryonic precursors of the vertebrobasilar and carotid systems, and may persist into adult life (3). It is the most common type of persistent primitive artery and is present in $0.1-0.6 \%$ of individuals $(3,4)$. Chordomas located primarily in the sellar region are uncommon, and may clinically present as non-functioning pituitary adenoma (13). To date, only 38 cases of ISC have been documented in the literature. Persistent primitive trigeminal artery (PPTA) has been reported to be associated with various vascular abnormalities such as brain aneurysms and arteriovenous malformations (AVMs), but rarely with tumors (4). The association of PPTA with intrasellar chordoma (ISC) is extremely rare, and only one case of a clival chordoma associated with PPTA has been previously reported. 
We report a case of a primary ISC associated with PPTA, which was preoperatively occluded using endovascular techniques, permitting further surgical resection of the tumor. Despite a recent review that described only 22 patients with primary ISC since 1960, our extensive retrospective review of the literature yielded 16 additional cases of chordoma with sellar involvement $(15,44)$.

\section{CASE REPORT}

A 32-year-old male presented to our outpatient clinic for surgical evaluation of a large sellar mass. He complained of intermittent retro-orbital headache, diplopia and right facial paresthesias. On physical examination, a right cranial nerve (CN) six palsy was observed, albeit there were no symptoms or signs of pituitary dysfunction. Ophthalmological examination revealed a right-sided afferent pupillary defect, a left temporal homonymous hemianopsia, and horizontal diplopia.

Computed tomographic (CT) scans revealed a large heterogeneous contrast-enhancing intrasellar mass ( $2.5 \times 3.4$ $x 2.8 \mathrm{~cm}$ ) with parasellar extension to the cavernous sinus, invasion of the sphenoid sinus, as well as erosion of the dorsum sellae and the sellar floor (Figure 1A, B). High resolution 1.5T magnetic resonance imaging (MRI) demonstrated that the lesion elevated and stretched the optic chiasm, protruded into both cavernous sinuses, and extended posteriorly to the prepontine cistern close to the basilar artery. The lesion enhanced heterogeneously after gadolinium administration, and exhibited moderate peripheral enhancement (Figure $1 C, D)$. A vessel-like structure was also identified within the tumor, extending from the right intracavernous internal carotid artery to the basilar artery, corresponding to a PPTA (Figure 1E). Because of these findings, cerebral angiography was performed and demonstrated that the basilar and carotid arteries proximal and distal to the PPTA were both well-developed; the left posterior cerebral comunicating artery $(\mathrm{PCOA})$ was permeable and right vertebral artery was hypoplastic. Balloon test occlusion (BTO) of the PPTA at 15 minutes did not reveal neurological changes. A microcatheter
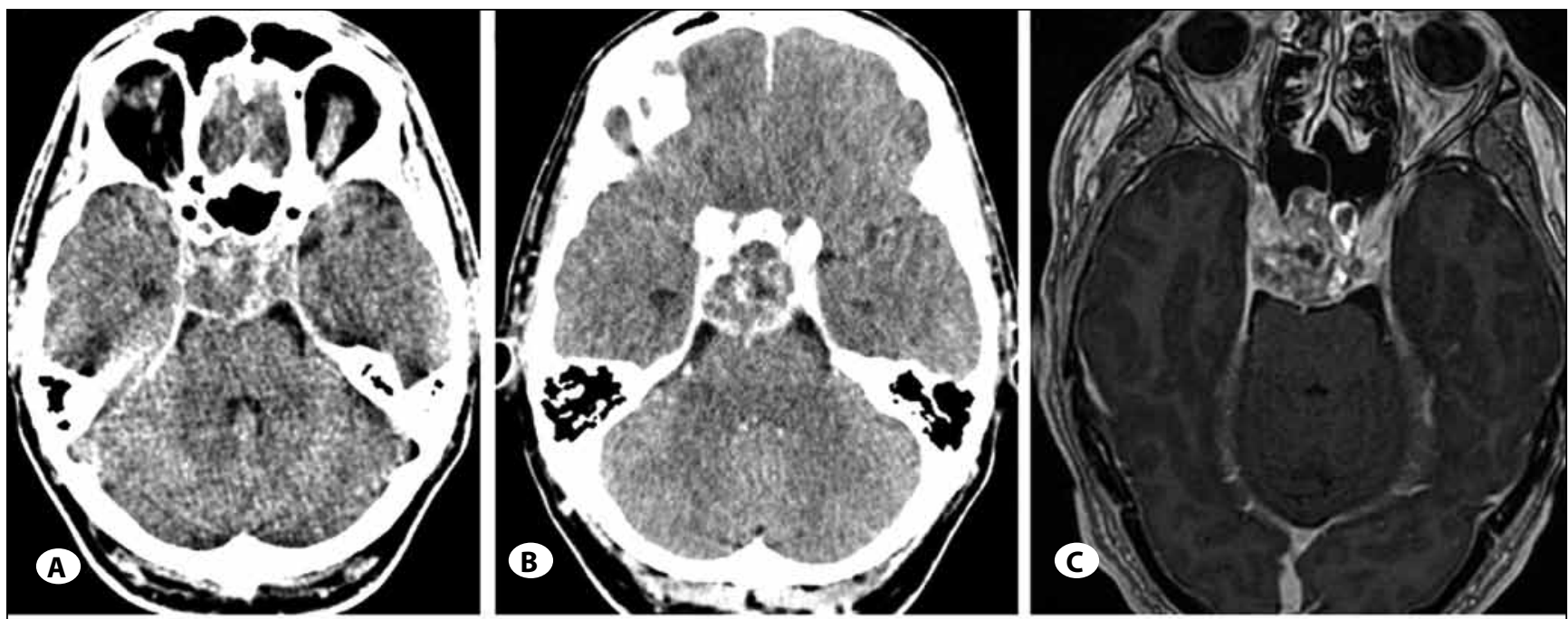
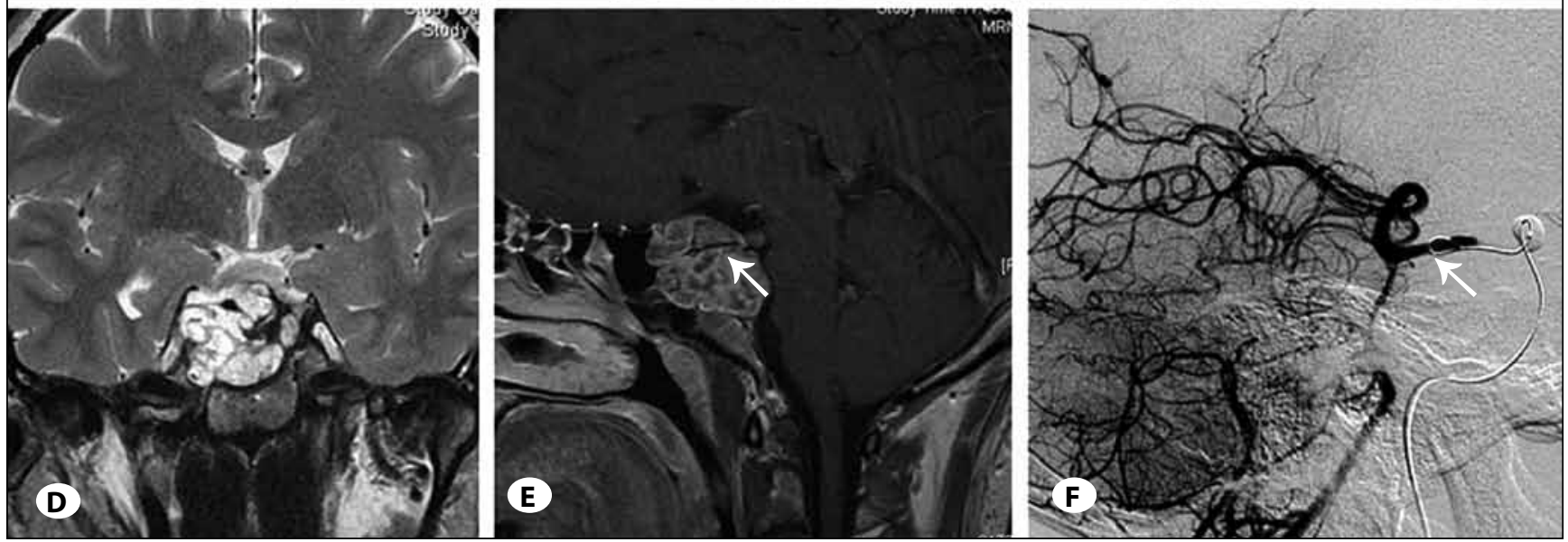

Figure 1: A) Non-contrast and B) contrast-enhanced axial CT scan. C) Axial T1-weighted MRI with contrast showing an enhancing, well circumscribed lesion. D) Coronal T2-weighted MR image demonstrating heterogeneous hyper- and hypo-intense signal of the tumor. E) Sagittal T1-weighted MR image with contrast that reveals a vascular tubular-like structure within the tumor (arrow). F) Preoperative cerebral angiogram vertebral injection confirming a PPTA (arrow). 
was subsequently used to catheterize the PPTA through the right vertebral artery, and $16 \mathrm{~cm}$ of coils were delivered for complete occlusion of the PPTA (Figure 1F).

Despite a slightly elevated basal prolactin level (26.4 ng/ $\mathrm{mL}$, reference value $3.5-19.5 \mathrm{ng} / \mathrm{mL}$ ) other endocrinological investigations of pituitary function were normal. Based on the endocrinological evaluation as well as preoperative CT, $\mathrm{MRI}$, and cerebral angiography, the presumed diagnosis of the lesion was ISC or chondrosarcoma associated with PPTA.

The patient underwent surgery for tumor resection, using a sublabial transsphenoidal (TSS) approach guided by neuronavigation. After opening the dura, a yellow, encapsulated, and soft lesion with a necrotic component was seen protruding into the sphenoid sinus. The tumor was debulked using microsurgical technique with bipolar forceps and pituitary curettes. The lateral and posterior limits of the lesion were moderately hemorrhagic and exhibited a rubbery consistency. The portion of the tumor adherent to the medial walls of the cavernous sinus could not be resected safely and so a subtotal resection was achieved.

Light microscopy revealed a solid pattern of cells arranged in cords. Neoplastic cells appeared embedded in a myxoid intercellular matrix and exhibited large, round eosinophilic cytoplasm containing multiple vacuoles, characterizing typical physaliphorous cells (Figure 2A, B). Immunohistochemical (IHC) analysis showed strong positivity for cytokeratin AE1AE3 as well as endothelial membrane antigen (EMA) (Figure 2C, D). The final pathological diagnosis was ISC.

Postoperatively, the patient did well and had no endocrinological impairments, except for transient diabetes insipidus. The patient experienced significant improvement of his right hemifacial paresthesias, diplopia and visual field deficit. MR



Figure 2: Photomicrographs obtained from tumor specimens. A) Hematoxylin and eosin (H\&E) stained (original magnification $x$ 200). B) Physaliphorous cells, with eosinophilic cytoplasm and multiple vacuoles (H\&E, original magnification $\times 400$ ). C) Immunohistochemical staining revealing the tumor cells to be strongly positive for cytokeratin AE1/ AE3 (original magnification x40). D) Chordoma cells showing focal staining for EMA (original magnification $\mathrm{x} 40$ ). 
study performed four months after the surgical procedure displayed subtotal tumor removal as well as optic chiasm and pons decompression (Figure 3A-C). Six months after surgery, the patient remained asymptomatic and was referred to the oncology department for radiotherapy.

\section{DISCUSSION}

Chordomas are rare, slow-growing malignant tumors that arise from remnants of the notochord and consequently are located rostrally and caudally along the midline of the neuroaxis $(6,15,27,44)$. Chordomas represent approximately $2 \%$ of all malignant tumors of the bone and $0.1 \%$ to $0.2 \%$ of all intracranial neoplasms (42). The incidence of intracranial chordomas shows a slight male predilection (6:5) and they often appear in younger patients. Approximately $50 \%$ of chordomas develop in the sacrococcygeal region, 35\% in the sphenoccipital region, and $15 \%$ in spinal vertebrae $(15,22)$. Chordomas primary involving the sellar region are rare (15).

The trigeminal artery is the largest of the fetal carotidbasilar anastomotic arteries. It persists for the longest embryonic period and is usually obliterated by the 11.5 to $14 \mathrm{~mm}$ embryonic stage, after the development of PCoA. Additionally, it is the most common of the primitive carotidbasilar anastomoses that persist into adulthood, with an estimated incidence of $0.1 \%$ to $1 \%$ on cerebral angiograms (3). PPTA has been reported to be associated with various vascular abnormalities, such as brain aneurysms and arteriovenous malformations (AVMs), and only rarely has it been described together with central nervous system (CNS) tumors (4). In fact, our case is only the second to describe a chordoma associated with PPTA. Baltsavias et al. reported the first case of a co-existing clival chordoma and PPTA that was lacerated during surgery (4). Thus, the present case is the first to document ISC associated with a PPTA.

A recent review by Hirosawa et al reported on 22 patients with ISC $(15,44)$. In the present study, however, we performed a systematic review of all cases of primary ISC previously reported in the literature since 1960 and identified 38 such cases (1, 2, 5, 7-17, 19-30, 32-38, 40-44, 46, 47). Table I summarises the clinical information recorded from the cases of ISC included in this study.

Neuroradiographical imaging features are useful in the preoperative diagnosis of skull base chordomas. On CT scans, these tumors are seen as slow-growing masses with bony erosion and calcifications or bone fragments within the tumor (5). CT can be more useful than MRI for detecting calcified masses such as chordoma $(5,45)$. On MRI chordomas usually appear hypointense on T1-weighted images (T1WI), whereas T2WI shows high-signal intensity. Calcifications or bone fragments appear as low-intensity areas in the tumor $(5,19)$. After gadolinium administration, ISC shows heterogeneous enhancement $(15,31)$. Additional studies with dynamic MR imaging and spectroscopy may help differentiate ISC from other skull base lesions $(27,44)$.

Histologically, chordomas are composed of lobules separated by fibrous tissue and neoplastic cells are arranged in cords, columns, or trabeculae. Ultrastructurally, chordomas lack malignant features such as necrosis or hemorrhage, although occasional mitotic figures and cellular pleomorphism may be present, that is of no prognostic significance $(5,15,44)$. The immunohistochemical profile of chordomas includes reactivity to cytokeratins, vimentin, and epithelial membrane antigen (EMA) (15). Chordomas containing a cartilaginous matrix are classified as chondroid chordoma (14).

The current published literature regarding the management of intracranial chordomas is mixed, but most authors agree that optimal treatment consists of gross-total surgical resection followed by high-dose local radiation therapy (1, $12,34,36)$. Gross-total resection is challenging, however, and can rarely be achieved given the anatomical constraints and infiltrative nature of the lesion. Subsequently, Crockard et al proposed that the surgical goal should be maximal, safe cytoreduction, with the least collateral damage (7). In
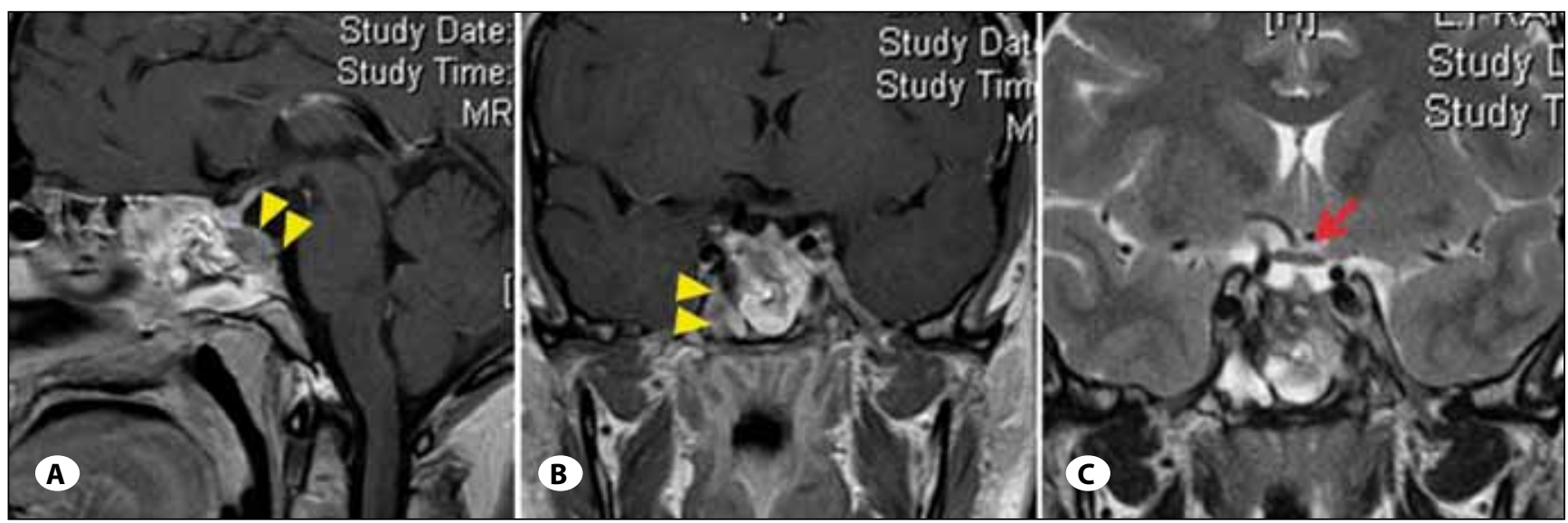

Figure 3A-C: MR study performed 4 months after the surgical procedure demonstrating wide decompression of the pons after subtotal tumor removal in addition to structures suggestive of the presence of filling materials (fatty tissue and hemostatic material). Arrowheads indicate residual tumor located at dorsum of sella and the right cavernous sinus. 


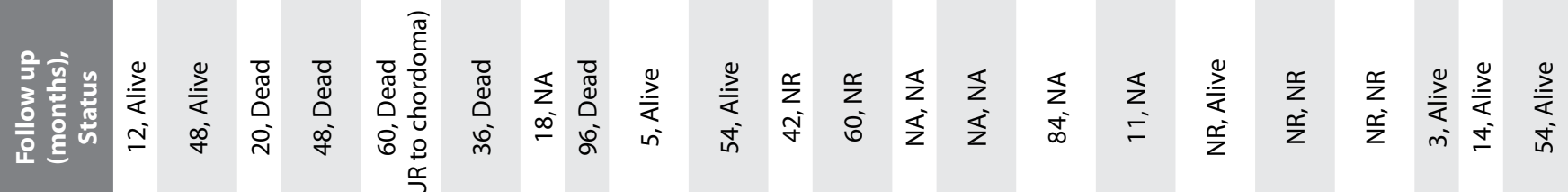

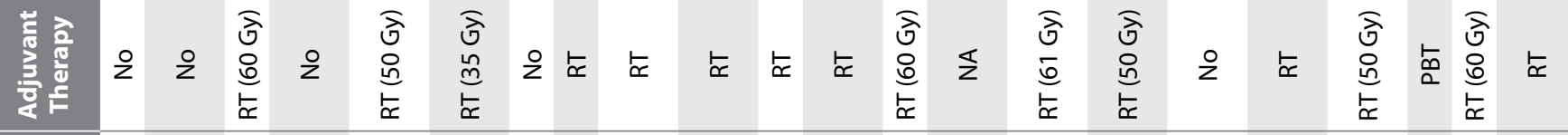

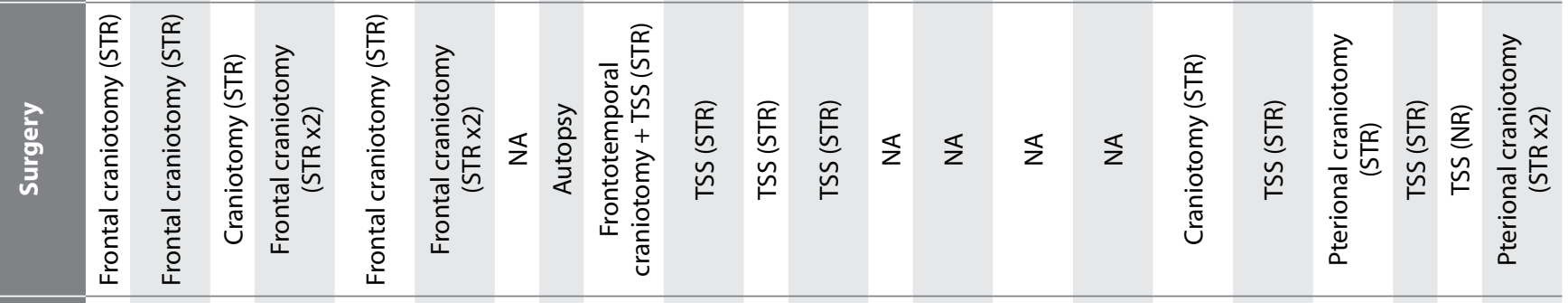

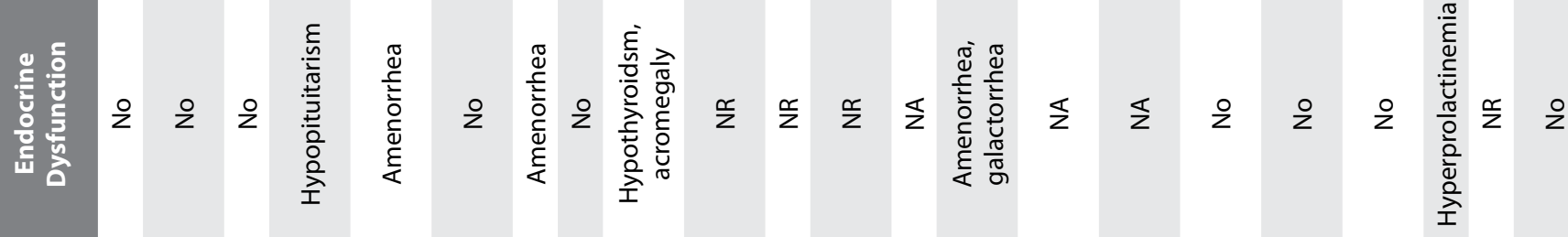

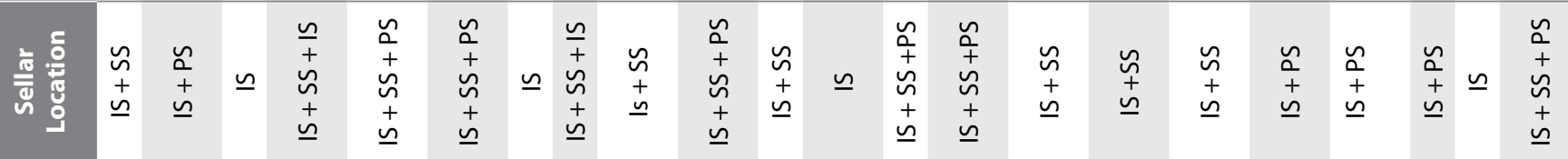

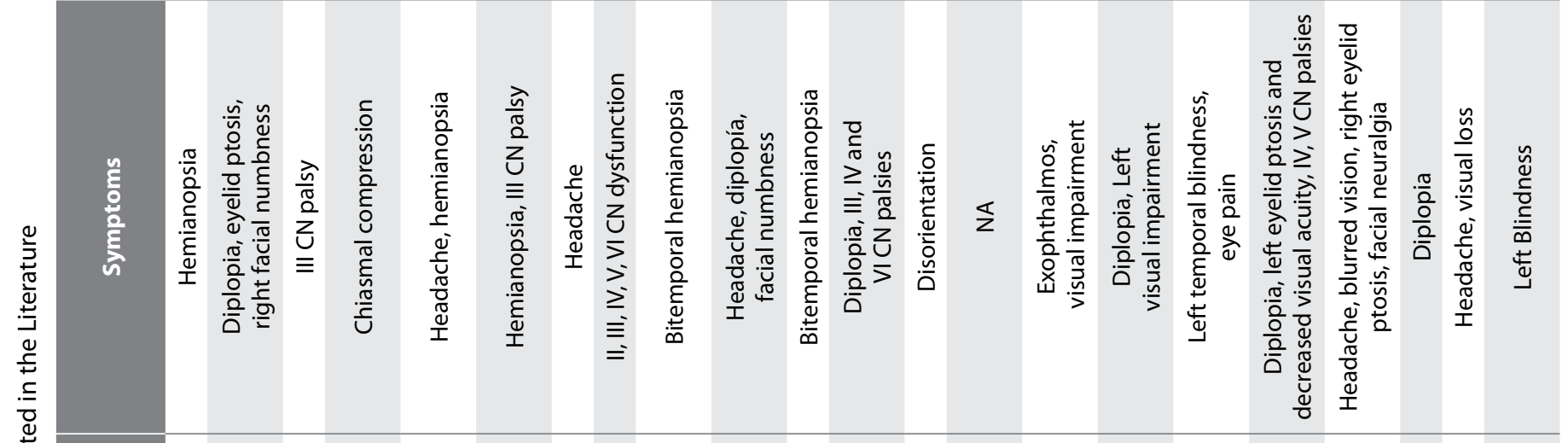

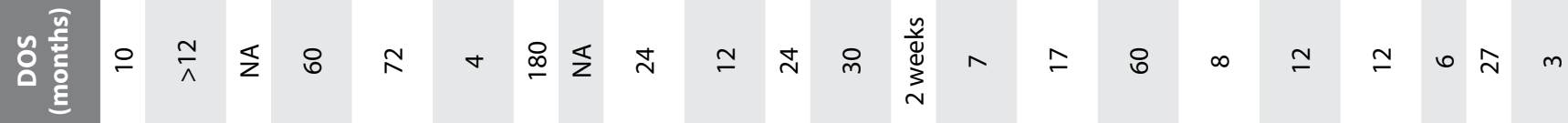

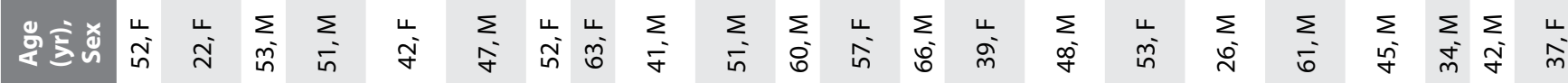

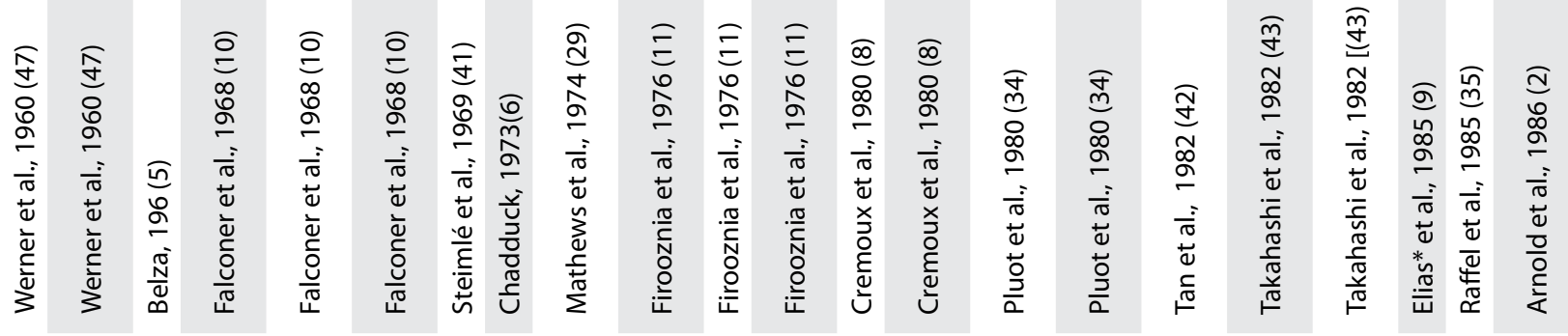




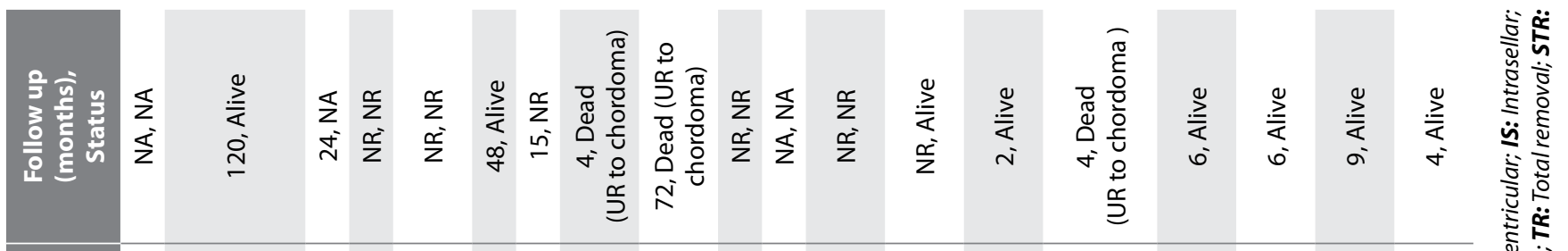
UI

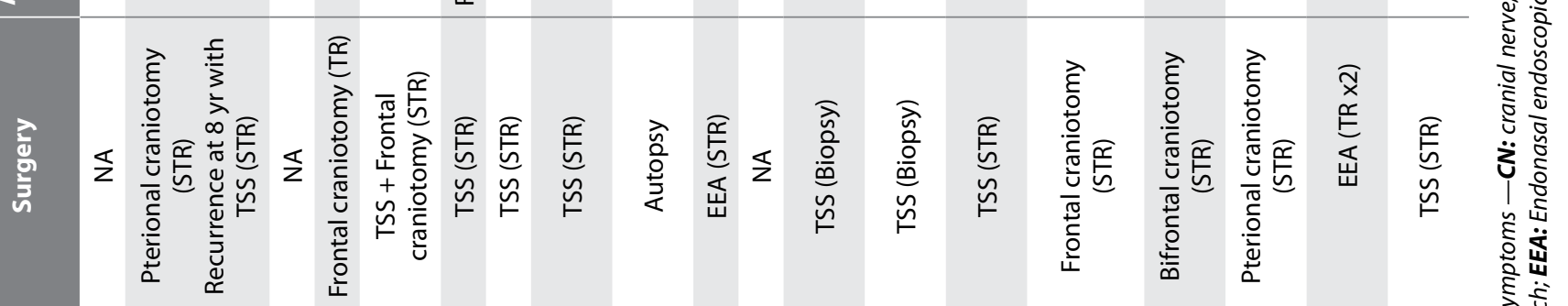

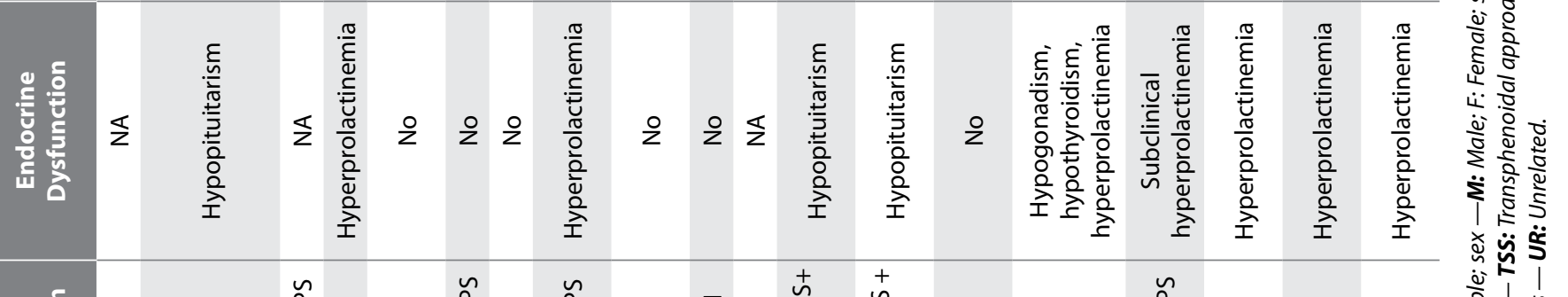

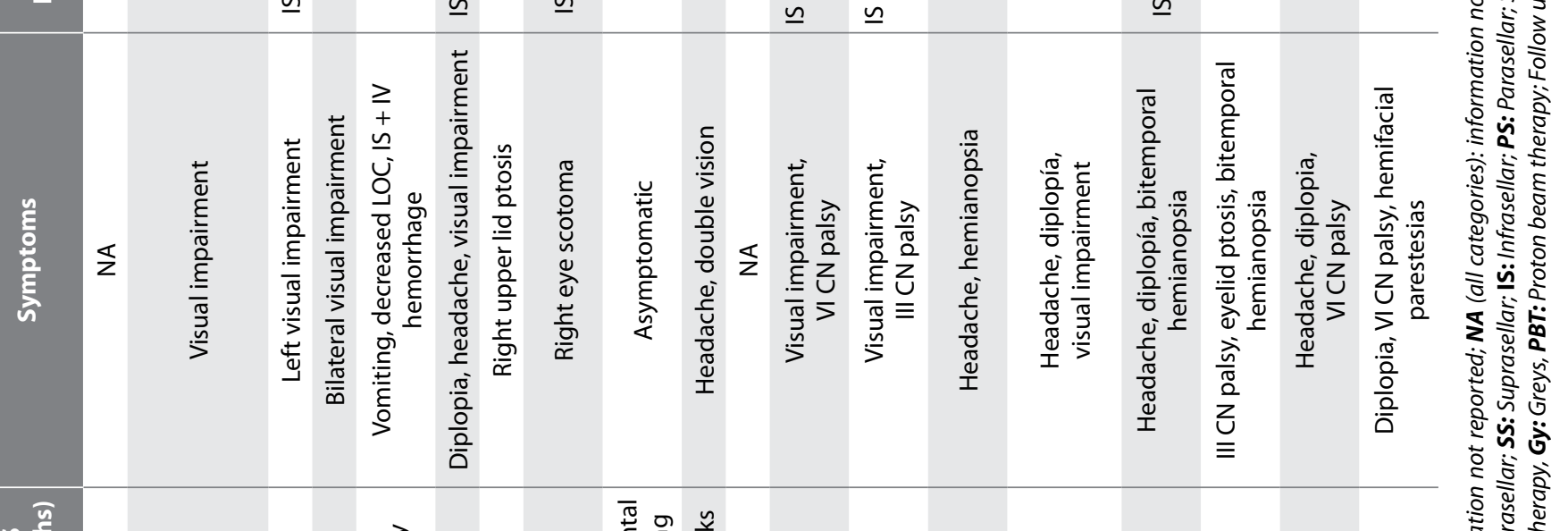

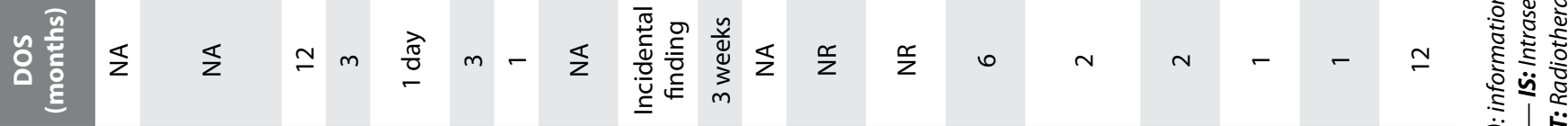

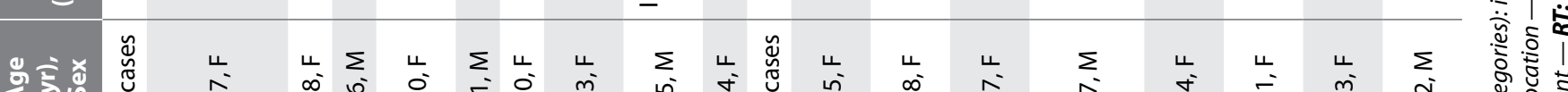

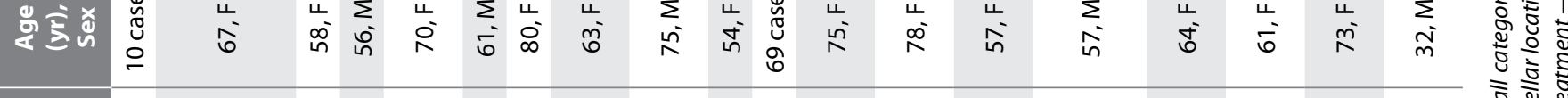

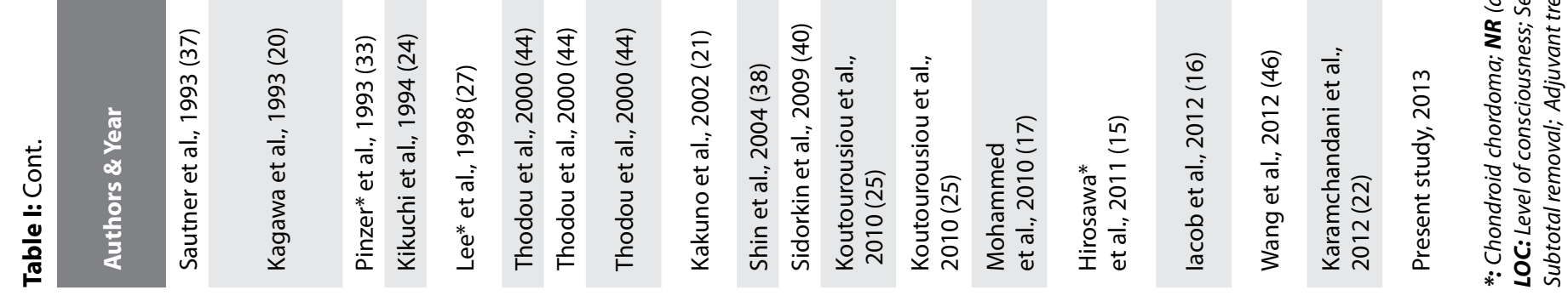


terms of operative approach, a variety of strategies have been developed to access skull base chordomas: transcranial, transsphenoidal (TSS), extended endonasal endoscopic (EEE), transpalatal and transmandibular approaches $(23,32$, $34,40)$. In cases of ISC, TSS and EEE approaches have been advocated allowing satisfactory tumor resection as well as decompression of the suprasellar compartment, optic chiasm and cavernous sinus $(17,26,34)$. The transcranial route was used widely throughout the 1950s and 1960s, perhaps following Cushing's abandonment of TSS $(7,28)$. Today, a transcranial approach may be indicated in cases of ISC with lateral suprasellar extension or in the setting of sphenoid sinusitis or ecstatic midline carotid arteries where a transnasal approach is contraindicated $(7,28)$. Our outcomes analysis of ISC cases summarized in Table I demonstrated a higher mortality rate in patients who underwent craniotomy (5 mortalities) versus TSS (1 mortality).

Because of the close proximity of skull base chordomas to vital structures and infiltrative nature of the tumor, the majority of chordoma resections are incomplete, and adjuvant radiation therapy is usually recommended (44). Conventional fractionated radiotherapy has been most commonly used, although there have been advancements in photon therapy (Gamma Knife, CyberKnife, and IMRT) that have helped to avoid excessive dosing to surrounding skull base tissues (1). Postoperative radiotherapy has been recommended to prolong disease-free survival, but its effect on improving overall survival is not well-established $(18,44)$.

Intraoperatorive hemorrhage from vascular structures, like the cavernous sinus, ICA, basilar artery, and persistence primitive vessels, may be potentially fatal and one of the most feared complications of TSS or EEE approaches. Subsequently, relationships of skull base tumors to intracranial vessels, should be carefully evaluated preoperatively with an angiogram, particularly when those surgical approaches are used (3). The decision to occlude PPTA must take into account the particular anatomical variation, branches, and its association with other cerebrovascular variants and disorders, all of which determine the safety of such a procedure $(3,4)$. This paper provides new insight into the need of suitable preoperative management of primitive carotid-basilar anastomoses that persist into adulthood before attempting surgical removal of sellar tumors, in order to achieve extensive surgical resection avoiding intraoperative life-threatening vascular complications.

\section{CONCLUSION}

Chordomas arising primarily in the sella turcica are rare lesions that may be misdiagnosed as non-functional pituitary adenoma. The association of ISC with PTTA is even more exceptional. Accurate preoperative diagnosis of ISC with vascular anomalies using MRI alone remains challenging because of its low incidence. For this reason, preoperative angiography may be indicated in select cases in order to allow for possible endovascular occlusion of the vascular anomaly identified. Modern microsurgical techniques together with endovascular occlusion of PPTA, can result in extensive surgical resection of ISC without intraoperative vascular complications.

\section{REFERENCES}

1. Alonso-Basanta M, Lustig RA, Kennedy DW: Proton beam therapy in skull base pathology. Otolaryngol Clin N Am 44:1173-1183, 2011

2. Arnold H, Herrmann HD: Skull base chordoma with cavernous sinus involvement. Partial or radical tumour-removal?. Acta Neurochir (Wien) 83:31-37, 1986

3. Azab W, Delashaw J, Mohammed M: Persistent primitive trigeminal artery: A review. Turk Neurosurg 22:399-406, 2012

4. Baltsavias G, Valavanis A: Endovascular occlusion of a lacerated primitive trigeminal artery during surgical resection of clival chordoma. A case report. Int Neuroradiology 16: 204-207, 2010

5. Belza J: Double midline intracranial tumors of vestigial origin: Contiguous intrasellar chordoma and suprasellar craniopharyngioma. Case report. J Neurosurg 25:199-204, 1966

6. Chadduck WM: Unusual lesions involving the sella turcica. South Med J 66:948-955, 1973

7. Crockard HA, Steel T, Plowman N, Singh A, Crossman J, Revesz T, Holton JL, Cheeseman A: A multidisciplinary team approach to skull base chordomas. J Neurosurg 95:175-183, 2001

8. De Cremoux P, Turpin G, Hamon P, de Gennes JL: Intrasellar Chordoma. Sen Hop 56:1769-1773, 1980

9. Elias Z, Powers SK: Intrasellar chordoma and hyperprolactinemia. Surg Neurol 23:173-176, 1985

10. Falconer MA, Bailey IC, Duchen LW: Surgical treatment of chordoma and chondroma of the skull base. J Neurosurg 29:261-275, 1968

11. Firooznia H, Pinto RS, Lin JP, Baruch HH, Zausner J: Chordoma: Radiologic evaluation of 20 cases. Am J Roentgenol 127: 797-805, 1976

12. Forsyth PA, Cascino TL, Shaw EG, Scheithauer BW, O'Fallon JT, Dozier JC, Piepgras DG: Intracranial chordomas: A clinicopathological and prognostic study of 51 cases. J Neurosurg 78:741-747, 1993

13. Gokalp HZ, Naderi S: A case of intracranial chordoma associated with pituitary adenoma. J Neurosurg Sci 35: 103-105, 1991

14. Heffelfinger MJ, Dahlin DC, MacCarty CS, Beabout JW: Chordomas and cartilaginous tumors at the skull base. Cancer 32:410-420, 1973

15. Hirosawa RM, Santos ABA, França MM, Fabris VE, Castro AVB, Zanini MA, Nunes VS: Intrasellar chondroid chordoma: A case report. ISRN Endocrinol 2011:259392, 2011

16. lacob G, Craciun M, Parascan L, Sajin M: Intra et parasellar chordoma. Case report. Rom Neurosurg 19:23-27, 2012

17. Jho HD, Carrau RL: Endoscopic endonasal transsphenoidal surgery: Experience with 50 patients. J Neurosurg 87:44-51, 1997 
18. Jian BJ, Bloch OG, Yang I, Han SJ, Aranda D, Parsa AT: A comprehensive analysis of intracranial chordoma and survival: A systematic review. Br J Neurosurg 25:446-453, 2011

19. Johnsen DE, Woodruff WW, Allen IS, Cera PJ, Funkhouser GR, Coleman LL: MR Imaging of the sellar and juxtasellar regions. Radiographics 11:727-758, 1991

20. Kagawa T, Takamura M, Moritake K, Tsutsumi A, Yamasaki $\mathrm{T}$ : A case of sellar chordoma mimicking a non-functioning pituitary adenoma with survival of more than 10 years. Noshuyo Byori 10:103-106, 1993

21. Kakuno Y, Yamada T, Hirano H, Mori H, Narabayashi I: Chordoma in the sella turcica. Neurol Med Chir (Tokyo) 42:305-308, 2002

22. Karamchandani J, Wu MY, Das S, Vogel H, Muller P, Cusimano M, Montanera W, Kovacs K: Highly proliferative sellar chordoma with unusually rapid recurrence. Neuropathology 33(4):424-430,2013

23. Kelly DF, Oskouian RJ, Fineman I: Collagen sponge repair of small cerebrospinal fluid leaks obviates tissue grafts and cerebrospinal fluid diversion after pituitary surgery. Neurosurg 49:885-890, 2001

24. Kikuchi K, Watanabe K: Huge sellar chordoma: CT demonstrataion. Comput Med Imaging Graph 18:385-390, 1994

25. Koutourousiou M, Kontogeorgos G, Seretis A: Nonadenomatous sellar lesions: Experience of a single centre and review of the literature. Neurosurg Rev 33:465-476, 2010

26. Koutourousiou M, Snyderman CH, Fernandez-Miranda J, Gardner PA: Skull base chordomas. Otolaryngol Clin North Am 44:1155-1171, 2011

27. Lee HJ, Kalnin AJ, Holodny Al, Schulder M, Grigorian A, Sharer LR: Hemorrhagic chondroid chordoma mimicking pituitary apoplexy. Neuroradiology 40:720-723, 1998

28. Liu JK, Weiss MH, Couldwell WT: Surgical approaches to pituitary tumors. Neurosurg Clin N Am 14:93-107, 2003

29. Mathews W, Wilson CB: Ectopic intrasellar chordoma. Case report. J Neurosurg 40:260-263, 1974

30. Mohammed AR, Amin P: An usual cause of a sellar mass. BMJ Case Rep 20:2010, 2010

31. Nakasu Y, Nakasu S, Ito R, Mitsuya K, Fujimoto O, Saito A: Tentorial enhancement on MR images is a sign of cavernous sinus involvement in patients with sellar tumors. AJNR Am J Neuroradiol 22:1528-1533, 2001

32. Oostra A, Van Furth W, Georgalas C: Extended endoscopic endonasal skull base surgery: From the sella to the anterior and posterior cranial fossa. ANZ J Surg 82:122-130, 2012
33. Pinzer T, Tellkamp H, Schaps P: The intracranial chordoma. Case report of a chondroid chordoma growing destructively in the region of sella turcica. Zentralbl Neurochir 54:133-138, 1993

34. Pluot $M$, Bernard $M H$, Rousseaux $P$, Scherpereel $B$, Roth $A$, Caulet T: Two cases of sellar chordomas. Ultrastructural and histochemical study. Arch Anat Cytol Pathol 28:230-236, 1980

35. Raffel C, Wright DC, Gutin PH, Wilson CB: Cranial chordomas: Clinical presentation and results of operative and radiation therapy in twenty-six patients. Neurosurg 17:703-710, 1985

36. Samii A, Gerganov VM, Herold C, Hayashi N, Naka T, Mirzayan MJ, Ostertag H, Samii M: Chordomas of the skull base: Surgical management and outcome. J Neurosurg 107:319-324, 2007

37. Sautner D, Saeger W, Lüdecke DK: Tumors of the sellar region mimicking pituitary adenomas. Exp Clin Endocrinol 101: 283-289, 1993

38. Shin JH, Cho DS, Kim MH, Kim SH: Sellar chordoma mimicking pituitary adenoma. J Korean Neurosurg Soc 36:257-259, 2004

39. Sidorkin DV, Konovalov AN, Makhmudov UB, Shkarubo AN, Usachey Dlu, Shimanskii VN: Surgical treatment of skull base chordomas. Zh Vopr Neirokhir Im N N Burdenko 2:15-22, 2009

40. Sidorkin DV, Konovalov AN, Makhmudov UB, Usachey Dlu, Shkarubo AN, Shimanskii VN: Topographic variants of cranial chordomas. Zh Vopr Neirokhir Im N N Burdenko 3:14-18, 2009

41. Steimlé $R$, Coudry $H$, Pageaut G, Mallie $M$, Comte $D$, Jacquet $\mathrm{G}$ : Intrasellar chordoma- transphenoidal approach. Acta Neurochir (Wien) 20:237-247, 1969

42. Takahashi T, Kuwayama A, Kobayashi T, Watanabe M, Katoh T, Kageyama N: Transsphenoidal microsurgery of sellarparasellar chordomas. Neurol Med Chir (Tokyo) 22:141-146, 1982

43. Tan WS, Spigos D, Khine N: Chordoma of the sellar region. J Comp Assist Tomogr 6:154-158, 1982

44. Thodou E, Kontogeorgos G, Scheithauer BW, Lekka I, Tzanis $\mathrm{S}$, Mariatos P, Laws ER Jr: Intrasellar chordomas mimicking pituitary adenoma. J Neurosurg 8:1-7, 2000

45. Utne JR, Pugh DG: The roentgenologic aspects of chordoma. Am J Roentgenol Radium Ther Nucl Med 74:593-608, 1955

46. Wang H, Ma H, Ma CC, Luo Y, Ge P: Sellar chordoma presenting as pseudo-macroprolactinoma with unilateral third cranial nerve palsy. Chin J Cancer Res 24:157-170, 2012

47. Werner A: On two cases of intrasellar chordomas. Acta Neurochir (Wien) 23:436-443, 1960 